\title{
PENINGKATAN KUALITAS SISWA DALAM MENGUASAI BAHAN AJAR AL-QUR'AN HADIS MELALUI PENAMBAHAN MATERI MATRIKULASI YANG EFEKTIF DAN INOVATIF
}

\author{
Yeti Herliza \\ MAN 2 Kota Bengkulu \\ yetiipuh12@yahoo.com
}

\begin{abstract}
ABSTRAK
Tujuan penelitian ini adalah menganalisis seberapa jauh upaya peningkatan kualitas siswa dalam menguasai bahan ajar Al-Qur'an Hadits, menganalisis muatan materi matrikulasi kelas X tingkat Madrasah Aliyah dan menganalisis metode yang efektif dan inovatif dalam penyampaian materi matrikulasi. Metode penelitian menggunakan pendekatan campuran, eksplorasi sekuensial Pengumpulan data dengan wawancara dan observasi yang kemudian dilanjutkan dengan instrumen survey dalam bentuk angket. Hasil penelitian, adanya peningkatan kualitas siswa dalam memahami dan mengaplikasikan materi pelajaran baik dari hasil evaluasi kognitif maupun aplikatifnya antara lain : siswa dalam waktu yang cukup bisa membaca Al-Qur'an bagi yang belum, semakin baik dan faseh cara membaca Al-Qur'an, mudah memahami hadits-hadits dalam materi pembelajaran. Simpulan, dari hasil penelitian yang telah dilakukan, melalui tambahan pembelajaran matrikulasi yang efektif dan inovatif dapat meningkatkan kualitas siswa dalam menguasai bahan pembelajaran Al-Qur'an Hadist.
\end{abstract}

Kata Kunci: Kualitas, Bahan Ajar, Materi Matrikulasi

\begin{abstract}
The purpose of this study is to analyze how far the efforts to improve the quality of students in mastering Al-Qur'an Hadith teaching materials, analyzing the content of matriculation material class X Madrasah Aliyah level and analyzing effective and innovative methods in the delivery of matriculation material. The research method uses a mixed approach to the Exploratory Sequential Design. Data collection by interview and observation which then continued with survey instruments in the form of a questionnaire. The results of the study, an increase in the quality of students in understanding and applying subject matter both from the results of cognitive evaluation and its application include: students in sufficient time can read the Al-Qur'an for those who have not, the better and phase reading the Qur'an, easy to understand the hadiths in learning material. Conclusions, from the results of research that has been done, through the addition of effective and innovative matriculation learning can improve the quality of students in mastering Al-Qur'an Hadith learning materials.
\end{abstract}

Keywords: Quality, Teaching Materials, Matriculation Materials 


\section{PENDAHULUAN}

Al-Qur'an adalah pedoman dan tuntunan hidup bagi manusia dalam menjalani semua proses kehidupan agar mendapatkan kebahagiaan di dunia dan akhirat. Al-Qur'an adalah kalamullah yang wajib diimani oleh orang muslim, karena tidak ada keraguan sama sekali di dalamnya. Seperti Firman Allah dalam surah Al-baqarah ayat 2 yang artinya "Inilah kitab yang tidak ada keraguan atasnya, sebagai petunjuk bagi orang-orang yang bertaqwa." Oleh karena itu merupakan suatu kewajiban bagi seorang muslim untuk selalu berinteraksi aktif dengan Al-Qur'an, menjadikannya sebagai sumber inspirasi, berpikir dan bertindak (Manna khalil al-Qattan, 2011).

Membaca Al-Qur'an merupakan langkah pertama berinteraksi denganNya kemudian diteruskan dengan tadabbur yaitu dengan merenungkan dan memahami maknanya sesuai petunjuk salafus shalih, lalu mengamalkannya dalam kehidupan sehari-hari, kemudian dilanjutkan dengan mengajarkannya, sebagaimana hadits nabi yang diriwayatkan oleh Bukhari yang artinya "Sebaik-baik kamu adalah yang mempelajari Al-Qur'an dan mengajarkannya." Setelah Al-Qur'an sebagai pedoman hidup utama bagi umat muslim adalah hadits-hadits yang yang disampaikan Rasulullah untuk memberikan penjelasan dari ayat Al-Qur'an sehingga sempurnalah tuntunan hidup bagi kita untuk meraih dan menggapai sebagai seorang hamba Allah yang sesungguhnya diciptakan adalah untuk berbakti kepada Allah Swt.

Sebagai seorang siswa di tingkat Madrasah Aliyah atau tingkat sekolah menengah atas yang usianya berkisar antara $14-18$ tahun yang disebut juga dengan masa pubertas karena pada masa ini seorang anak tidak hanya bersifat reaktif, tetapi anak juga mulai aktif mencapai kegiatan dalam rangka menemukan dirinya (akunya), serta mencari pedoman hidup untuk bekal hidupnya mendatang. Tentang tanda-tanda masa pubertas ini E. Spranger, menyebutkan ada tiga aktivitas yakni penemuan aku, pertumbuhan pedoman kehidupan dan memasukkan diri pada kegiatan kemasyarakatan (Kemenag RI, 2014).

Lembaga pendidikan Madrasah salah satu satuan pendidikan di bawah Kementerian Agama sangat memperhatikan dan mengutamakan pendidikan anak yang berkarakter yang lebih menitikberatkan pada akhlak yang bersumber dari materi-materi rumpun PAI yang ada di Madrasah. Madrasah dalam hal ini merupakan titik awal dari era kebangkitan bagi kemapanan sistem pendidikan Islam, tetapi karena lembaga-lembaga pendidikan Islam sebelumnya dinilai tidak lagi mampu memenuhi kebutuhan dan tuntutan umat muslim, maka kelahiran madrasah agaknya menjadi keharusan historis demi terwujudnya sistem kelembagaan pendidikan Islam yang profesional.

Kurikulum dan metode pendidikan Islam yang ada didalamnya dikembangkan dan disesuaikan agar dapat ikut berperan bagi kemajuan peradaban Islam. Salah satu materi PAI di madrasah adalah yang terintegrasi dalam rumpun PAI yaitu mata pelajaran Al-Qur'an Hadis yang mempelajari tentang ayat-ayat Al- 
Qur'an dan Hadis sesuai dengan tema dan sub tema untuk 2 semester khusus kelas X (sepuluh) jenjang Madrasah Aliyah (Kemenag RI, 2014).

Penelitian Gahu (2016) menunjukkan bahwa pada umumnya semua guru Al-Qur'an-Hadis sudah mempersiapkan rancangan pembelajaran sebelum mengajar, namun kemampuan guru dalam merancang masih membutuhkan pengembangan sesuai dengan kebutuhan, dan perkembangan peserta didik. Dalam mengembangkan desain pembelajaran guru Al-Qur'an-Hadis mengalami berbagai macam kendala yakni, kurangnya referensi tentang pembelajaran Al-Qur'anHadis di perpustakaan, terbatasnya media pembelajaran, kemampuan guru dalam menggunakan teknologi, dan peserta didik yang tidak mampu membaca al-Qur'an.

Dalam menanggulangi faktor penghambat tersebut pihak sekolah dalam hal ini kepala madrasah, wakamad bidang kurikulum dan guru bidang studi telah melakukan usaha. Kepala madrasah telah bermohon ke kementerian agama untuk permintaan buku referensi, dan fasilitas berupa media dan software pembelajaran. Wakamad dan guru telah melakukan sosialisasi dengan komite sekolah dan alumni MAN I tentang kendala tersebut. Disamping faktor penghambat ada faktor pendukung guru dalam mengembangkan desain pembelajaran. Untuk mengembangkan wawasan dan kompotensi guru sehingga mudah mengembangkan desain pembelajaran, pihak sekolah memberdayakan jaringan internet di lingkungan sekolah, membentuk team teaching, memberikan motivasi kepada guru untuk melanjutkan studi, melakukan suvervisi di kelas, dan mengutus guru untuk mengikuti pelatihan dan seminar demi pengembangan kompotensi guru. Untuk peningkatan kemampuan baca al-Qur'an peserta didik diadakan privat baca al-Qur'an tiga kali dalam satu minggu.

Hasil penelitan dari Buna'i (2012) mendiskripsikan manajemen pembelajaran Al-Qur'an Hadits dalam perencanaan, pelaksanaan dan evaluasi pembelajaran mapel Qur'an Hadits. Kata kunci dalam manajemen pembelajaran Al-Qur'an Hadits adalah pendidikan yang dapat dijadikan salah satu wahana untuk meningkatkan kualitas manusia sehingga peningkatan mutu pendidikan harus dimulai dari usaha peningkatan kualitas tenaga pendidik, sarana yang memadai, biaya dan kemudahan lainnya yang relevan dengan kurikulum serta guru selaku pendidik hendaknya selalu menjadi kan dirinya suri tauladan yang baik bagi anak didiknya. Maka berkaitan dengan hal ini, pekerjaan di bidang pendidikan hendaknya dilakukan oleh orang-orang yang benar-benar profesional dalam dunia pendidikan sehingga dapat mengaplikasikan ilmu-ilmu pendidikan yang sudah dimiliki. Untuk menjadikan guru bermutu dalam profesinya maka dituntut adanya karakteristik dirinya terutama kreatif dalam hal yang berkaitan dengan profesi belajar mengajar dan penempatan posisi tenaga pendidik tersebut disesuaikan dengan keahliannya.

Selanjutnya mengenai penggunaan metode mengajar yang kuran sesuai dengan kondisi siswa baik itu dari segi kondisi lingkungan lembaga pendidikan, kultur masyarakatnya, segi ekonomi dan sebagainya. Di MAN Pamekasan sejak 
tahun 2000 sampai sekarang banyak diminati oleh masyarakat. Hal ini adalah salah satu indikasi bahwa MAN Pamekasan adalah madrasah yang bermutu khususnya dalam bidang pembelajaran semua ini tidak lepas dari mutu gurunya, dalam bidang mapel Al-Qur'an Hadits gurunya melakukan inovasi-inovasi pembelajaran yang bisa mengantarkan peserta didiknya ke berbagai perlombaan pada tingkat nasional dalam bidang Al-Qur'an karena pembelajaran Al-Qur'an Hadis juga tidak hanya dilaksanakan dikelas saja MAN Pamekasan juga sudah punya Laboratorium Al-Qur'an.

Muhammad Nasir (2014) temuan penelitian memperlihatkan bahwa; a) hasil uji coba terbatas dan uji coba luas dengan tiga kategori Madrasah Eksperimen (ME) menunjukkan adanya peningkatan signifikan pemahaman siswa kelas XI dalam mata pelajaran Alquran hadis setelah perlakuan model hasil pengembangan $(\mu \leq 0,05)$; b) hasil uji validasi menunjukkan adanya perbedaan pemahaman signifikan antara skor rata-rata posttest kelompok Madrasah Eksperimen dengan skor rata-rata posttest kelompok Madrasah Kontrol $(\mu \leq 0,05)$. Dengan demikian, model pembelajaran kooperatif tipe grup investigasi hasil pengembangan, efektif dalam meningkatkan pemahaman siswa kelas sebelas pada mata pelajaran Alquran Hadis. Penelitian ini perlu untuk lebih menggali upaya yang dapat dilakukan pada siswa madrasah untuk meningkatkan kualitas dan pemahaman siswa dalam mempelajari Al-qur'an dan hadits melalui kegiatan matrikulasi yang efektif dan inovatif.

\section{METODE PENELITIAN}

Penelitian ini menggunakan pendekatan campuran dengan jenis metode eksplorasi sekuensial yang diawali dengan upaya peneliti melakukan pengumpulan data dengan teknik wawancara atau observasi untuk memahami berbagai persoalan yang sesuai dengan objek dan konteks yang akan diteliti. Hasil penelusuran data tersebut di analisis dengan seksama dengan menggunakan caracara-cara yang biasa dilakukan dengan pendekatan kualitatif. Pemahaman yang utuh terrhadap objek penelitian menjadi dasar yang kuat untuk merumuskan instrumen survei yang akan digunakan. Instrumen survei dalam bentuk angket sebagaimana dalam metode kuantitatif disebarkan untuk selanjutnya diolah untuk mendapatkan simpulan kuantitatif yang kemudian dilakukan penafsiran. Penelitian dilaksanakan di Madrasah Aliyah Negeri (MAN) 2, dengan jumlah siswa 298 orang yang tebagi 8 rombel serta dengan 2 orang guru Al-Qur'an Hadits, teknik pengumpulan data dalam penelitian ini adalah wawancara, observasi, angket dan tes lisan.

\section{HASIL DAN PEMBAHASAN}

Untuk mencapai pelayanan yang cepat dan akurat serta meningkatkan efektivitas pembelajaran yang maju MAN 2 Kota Bengkulu memanfaatkan dukungan teknologi informasi pada setiap produk layanan. Saat ini MAN 2 Kota 
Bengkulu memiliki peralatan TIK yang dapat berfungsi secara baik dengan rincian sebagai berikut: Komputer/P.C. unit sebanyak 75 unit, Komputer laptop sebanyak 20 unit dan Printer sebanyak 25 unit. Penggunaan halaman taman 549 $\mathrm{m} 2$ dan lapangan olahraga $744 \mathrm{~m} 2$. Sebagaimana di jeaskan oleh Ibu Karmila sebagai kepala MAN 2 :

"Sarana dan prasarana yang ada di MAN 2 ini sangat menunjang proses pembelajaran. Khusus untuk program matrikulasi MAN 2 punya sarana ibadah seperti masjid sangat luas bisa menampung seribu orang siswa, jadi untuk sekitar siswa kelas $X$ yang mengikuti program matrikulasi ini sangat kondusif sekali karna pembelajaran di laksankan pada waktu ketika pembelajaran sudah berakhir yaitu dari jam $14.00 \mathrm{~s} / \mathrm{d} 16.30 \mathrm{wib}$ selama 2 hari yaitu Senin dan Selasa”.

Pelaksanaan penelitian ini diawali dengan observasi bapak/ibu guru yang menyampaikan materi matrikulasi yang berkaitan dengan mata pelajaran AlQur'an Hadits, mengamati saat materi disampaikan serta metode yang mereka gunakan observasi ini di laksanakan untuk beberapa kali. Observasi juga dilakukan dalam teknik pengumpulan data yang merupakan teknik pengumpulan data yang tidak begitu sederhana dan tidak memerlukan keahlian yang luar biasa, walaupun demikian ada ketentuan-ketentuan khusus yang harus ditaati, agar observasi dapat berjalan dengan baik. Teknik observasi digunakan dalam penelitian ini adalah untuk mengamati segala aspek yang muncul atau terjadi pada saat proses pembelajaran Al-Qur'an Hadits berlangsung di kelas yang terkait dari hasil dari kegiatan pembelajaran matrikulasi yang telah diberikan untuk mengukur sejauh mana keberhasilan dari program tersebut.

Penerimaan Peserta Didik Baru (PPDB) tahun pelajaran 2018/2019 di laksanakan pada awal bulan Mei setelah anak kelas XII tingkat SLTA dan kelas IX tingkat SLTP Ujian Nasional, peserta didik baru yang bisa diterima di MAN 2 Kota Bengkulu setelah melalui tes tertulis dan tes lisan mereka diluluskan berdasarkan nilai tes yang mereka terima yang sudah melalui seleksi nilai dan perangkingkan komulatif. Adapun materi-materi tes yang mereka berikan adalah secara umum yang terdiri dari beberapa mata pelajaran ( matematika, bahasa, agama dan psikologis ) sedangkan materi PAI sangat sedikit sekali, karena itulah peserta didik baru sebagai calon kelas $\mathrm{X}$ di MAN 2 Kota beragam dan sangat bervariasi kemampuan dan pengetahuannya terhadap mata pelajaran PAI terutama bahan pelajaran atau materi PAI umtuk tingkat MAN sangat banyak dan cukup luas terutama Al-Qur'an Hadis yang banyak kaitan dan sinkronisasinya dengan Al-Qur'an itu sendiri di tambah lagi latar belakang pendidikan dan pekerjaan orang tua, daerah asal mereka, asal sekolah dan lingkungan tempat tinggalnya.

Dilanjutkan dengan teknik wawancara dengan beberapa guru matrikulasi yang terdiri dari 20 orang sebagai informan utama ada beberapa pertanyaan wawancara yang disampaikan yang mencakup tentang materi matrikulasi yang 
mendorong percepatan tersampaikan kepada siswa materi mata pelajaran AlQur'an Hadits, metode dan strategi pembelajaran yang seefektif mungkin dan banyak berinovasi sesuai dengan tingkat perkembangan usia remaja di tingkat madrasah aliyah (SLTA) dalam kegiatan pembelajaran.

Peneliti menetapkan informan yang bisa membantu menjelaskan data yang akan dianalisis berkaitan dengan permasalahan yang diteliti antara lain informannya adalah guru PAI MAN 2 sebanyak 13 orang, kepala madrasah, waka kesiswaan, waka kurikulum dan guru BK. Dengan memperhatikan kondisi ini guru PAI yang ada di MAN 2 mencari solusi yang tepat agar pembelajaran dapat berjalan dengan baik dan seimbang bagi semua peserta didik khususnya untuk kelas X, matrikulasi yang disampaikan dengan metode inovatif dan efektif adalah salah satu solusi yang tepat untuk diterapkan dengan cara mengelompokkan peserta didik kedalam tiga tingkatan yaitu tingkatan yang pertama adalah peserta didik yang masih buta baca tulis Al-Qur'an, tingkatan yang kedua peserta didik yang sudah bisa membaca Al-Qur'an tetapi masih belum terlalu lancar dan tingkatan yang ketiga adalah peserta didik yang sudah faseh membaca Al-Qur'an. Dalam pelaksanaan dan penyampaian materi saat matrikulasi guru PAI/guru mapel Al-Qur'an Hadis dan dibantu dengan guru honor, sebagaimana disampaikan oleh ibu Herawati, M.Ag :

"Pengelompokan siswa dalam program matrikulasi berdasarkan pada kemampuan mereka membaca Al-Qur'an untuk yang benar-benar belum bisa mereka diajarkan dari Iqra' 1 sampai Iqra' 6, bagi sudah bisa membaca Al-Qur'an mereka diberi materi tajwid dan qiro'ah serta yang sudah baik dan benar membaca Al-Qur'annya di wajibkan mengikuti tahfiz juz 30".

Berdasarkan data dokumentasi yang penulis ambil yaitu jadwal dan hasil evaluasi akhir dari program matrikulasi tersebut dengan bentuk buku laporan hasil belajar matrikulasi keagamaan siswa kelas X tahun pelajaran 2018/2019 selama 1 tahun siswa kelas $X$ harus hafal hadis-hadis pilihan sebanyak 40 hadis, seperti yang disampaikan oleh ibu Umi Kalsum, M.Pd.I :

Dalam program hafalan hadits-hadits pilihan dan harian siswa kelas $X$ diberi materi hadis dengan cara setoran setiap pertemuan sesuai dengan tingkat kemampuan siswa itu sendiri serta hadis yang diberikan kepada mereka terkait dengan pelajaran-pelajaran Al-Qur'an Hadits dan Mapel PAI lainnya.

Materi Matrikulasi yang sangat membantu dalam mata pelajaran Al-Qur'an Hadits antara lain adalah ilmu Tajwid dan semua yang berkaitan dengan tajwid, ulumul Qur'an, Ulumul Hadits, Program Hafalan Qur'an dan Metode Iqra', Hadits Harian Untuk membentuk Karakter Islami, Praktek Ibadah yaumiyyah, dan materi Bahasa Arab dengan menggunakan modul khusus untuk siswa baru yang sudah 
rangkum oleh tim matrikulasi. Seperti yang diungkapkan oleh Bapak Arqam, M.Pd :

"Program matrikulasi disamping membantu siswa dalam bimbingan membaca Al-Qur'an dengan baik dan benar yang tidak kalah pentingnya adalah juga membimbing siswa untuk berakhlak yang bagus dengan berbagai program yang tercakup dalam matrikulasi seperti bagaimana akhlak kepada guru, orang yang lebih tua dari kita, yang lebih kecil, terhadap lingkungan bahkan sampai bagaimana adab makan dan berbicara yang sopan santun”.

Langkah selanjutnya adalah melakukan teknik pengumpulan data dengan instrumen survei dalam bentuk angket yang menjadi populasi sampelnya adalah siswa yang sudah terbagi dalam tiga kelompok. Adapun pertanyaan-pertanyan yang diajukan mengarah kepada apa saja perubahan di rasakan langsung oleh siswa tersbut setelah mendapatkan tambahan materi matrikulasi dari program Madrasah itu sendiri yang dilanjutkan dengan tes secara lisan oleh peneliti sendiri kebeberapa siswa. Pertanyaan juga mencakup bagaimana metode yang bapak/ibu guru terapkan dalam penyampaian materi-materi Matrikulasi tersebut. Jumlah seluruh siswa kelas X tahun Pelajaran 2018/2019 adalah 304 orang

Adapun yang menjadi sampel dalam penelitian ini adalah sebanyak 90 orang yang terdiri dari tiga tingkatan/kelompok yang berdasarkan pada kemampuan dan kompetensi siswa itu sendiri. Dan untuk menyempurnakan penelitian ini peneliti juga mengambil data terhadap wali siswa berkaitan dengan materi dan waktu pembelajaran matrikulasi serta ada tidaknya pengaruh terhadap peningkatan belajar anak tersebut. Orang tua/wali siswa diberikan angket untuk mengumpulkan data tentang bagaimana peningkatan anaknya dalam pembelajaran di Madrasah

Berdasarkan hasil penelitian diatas, menindaklanjuti Surat Keputusan Bersama tiga Menteri tahun 1976 Menteri Agama mengeluarkan keputusan tentang pemberlakuan Kurikulum Madrasah, berdasarkan kurikulum ini, mata pelajaran di Madrasah memuat 30\% pendidikan agama meliputi Qur'an Hadits, Aqidah Akhlak, Fiqh, Sejarah dan Kebudayaan Islam, dan Bahasa Arab serta 70\% pendidikan umum. SK Mendikbud Nomor 489/U/1992 tentang sekolah menengah umum menyatakan bahwa Madrasah Aliyah adalah Sekolah Menengah Umum yang berciri khas agama Islam yang diselenggarakan oleh Kementerian Agama (Kemenag RI, 2014).

Mata Pelajaran Al-Qur'an Hadis adalah salah satu mata pelajaran dalam rumpun PAI ( Al-Qur'an Hadis, Fiqh, SKI dan Aqidah Akhlak) kelas X tingkat Madrasah Aliyah yang sangat strategis untuk dipelajarai, dipahami, dikuasai dan diamalkan dalam keseharian seorang siswa yang dalam masa remaja adalah masa yang galau, labil dan tidak konsisten, ada begitu banyak istilahistilah aneh yang disematkan untuk para remaja yang sedang dalam masa 
pencarian jati diri. Apalagi mereka bisa mengenal lebih dalam tentang AlQur'an itu sendiri. Al-Qur'anul Karim adalah mukjizat Islam yang kekal dan mukjizatnya selalu diperkuat oleh kemajuan ilmu pengetahuan (Ahmad Tafsir, 2012)

Materi pelajaran Al-Quran Hadits Madrasah Aliyah Kelas X yaitu : AlQur'an Kitab-ku, Betapa otentiknya kitab-ku, Tujuan dan Fungsi Kitab-ku, Pokokpokok Isi Kitab-ku, Manusia sebagai Hamba Allah dan Khalifah di Bumi, Memahami Hadis, Sunnah, Khabar dan Atsar, Memahami unsur-unsur Hadis, Betapa bermacam-macamnya Sunnah Nabi-ku, Memahami Hadis dari Segi Kuantitasnya, Indahnya Ikhlas dalam Beribadah. Dengan memperhatikan materi mata pelajaran Al-Qur'an Hadis kelas X Madrasah Aliyah sangat bersinergi dengan pembelajaran pada program matrikulasi disamping membahas tentang AlQur'an cara membacanya, memahaminya, mempelajarinya disamping itu mempelajari hadis juga tidak kalah pentingnya dengan belajar Al-Qur'an yang mana hadis adalah seluruh yang disandarkan kepada Nabi Saw baik berupa perkataan, perbuatan dan ketetapannya. Rasulullah adalah uswatun hasanah bagi kita karena terhimpunnya seluruh akhlakul karimah dan akhlak-akhlak utama pada diri Rasulullah Saw yang menjadi bekal dan pegangan hidup bagi kita untuk mendpatkan kebahagiaan yang hakiki. Dalam mata pelajaran Al-Qur'an Hadis semua aspek-aspek diatas dibahas sesuai dengan tingkat pemahaman dan perkembangannya.

Bahan materi Al-Qur'an Hadis untuk kelas X ada 10 BAB yang sudah di jelaskan diatas pada semester pertama membahas tentang Al-Qur'an dan ruang lingkupnya serta berkaitan dengan hakikat penciptaan manusia, akhlak dan adab menjalani kehidupan semua bahan dan materi tersebut diaawali dengan surahsurah dalam Al-Qur'an yang harus di pahami anak tafsir dan maknanya pada semester dua bahan dan materi yang berkaitan dengan Hadis dan ruang lingkupnya yang menunjukkan bahwa Rasulullah itu adalah uswatun hasanah bagi kita. Pada BAB terakhir materi mapel A-Qur'an Hadis sampai pada tingkat yang sangat besar pengaruh dengan apa yang ada pada materi sebelumnya yaitu tentang keikhlasan. Dengan gambaran seperti ini tambahan kegiatan pembelajaran untuk menyetarakan kompetensi peserta didik karena kesenjangan kompetensi itu akan memiliki konsekuensi pembelajaran di kelas selanjutnya, program matrikulasi diharapkan dapat memfasilitasi capaian taraf kemampuan atau entry level untuk menjamin keberhasilan pembelajaran di kelas XI dan XII (Tim Baitul Kilmah Jogjakarta, 2017).

Dari hasil penelitian diatas mata pelajaran Al-Qur'an Hadis benar-benar harus mendapat perhatian khusus dari semua pihak terutama guru rumpun PAI yang ada di MAN 2 dan orang tua, dengan matrikulasi yang diprogramkan oleh pihak madrasah jika seluruh peserta didik dapat memanfaatkannya dengan baik, sarana dan prasarana madrasah yang mendukung dalam penyampaian materi serta keseriusan, kesungguhan dan kecakapan dari guru matrikulasi akan mendapatkan 
kualitas dan mutu siswa dalam penguasaan materi Al-Qur'an Hadis yang bermuara pada pembentukan karakter serta siswa yang berakhlakul karimah sesuai dengan tuntunan Al-Qur'an dan mengikuti teladan-teladan yang sudah dicontohkan oleh Rasulullah/Hadis.

\section{SIMPULAN}

Berdasarkan hasil penelitian dan pembahasan di atas program matrikulasi yang efektif dan inovatif yang dilaksanakan oleh guru rumpun PAI di madrasah Aliyah Negeri (MAN) 2 Kota Bengkulu untuk kelas X dan diluar jam belajar dapat meningkatkan dan menyetarakan kompetensi peserta didik dalam mengikuti pelajaran Al-Qur'an Hadis yang sangat padat dengan Surah-surah Al-Qur'an dan Hadis-hadis serta materi-materi lain yang berkaitan dengan akhlak, adab, hakikat kehidupan manusia pentingnya rasa syukur dan ikhlas. Mata pelajaran Al-Qur'an Hadis adalah salah satu mata pelajaran yang sangat strategis sebagai sumber bagi peserta didik dalam memgembangkan pemikiran tentang begitu sempurnanya agama Islam dengan kitabnya Al-Qur'an yang merupakan mukjizat bagi Rasulullah, wahyu Allah Swt yang tiada keraguan sedikitpun atasnya serta tidak kalah pentingnya dari semua itu begitu banyaknya kisah teladan, aturan dan hukum, balasan dan ganjaran, keserasian dan keindahan, pelajaran dan hikmah, pengobatan fisik dan mental semua ada dalam Al-Qur'an sungguh suatu kesempurnaan jika kita memahami, mempelajari dan mengamalkannya.

\section{DAFTAR PUSTAKA}

Abu, A \& Munawar, S. (1992). Psikologi Perkembangan. Jakarta: PT.Rineka Cipta.

Ahmad, T. (2012). Materi Pendidikan Agama Islam. Bandung : PT. Remaja Rosdakarya

Buna'i. (2012). Manajemen Pembelajaran Al Qur'an Hadits di MAN Pamekasan. Jurnal Sosial Humaniora (Jsh) 5(2);158-192

Guru PAI MAN 2, Tahsin Qira'ah Bahan Ajar Al-Qur'an kelas X,Tim Pembina Martrikulasi Keagamaan, TP. 2016/2017

I'anatut, T. (2014). Statistika Pendidikan dan Metodologi Penelitian Kualitatif. Malang : Madani

Kemenag RI. (2014). Buku Siswa Al-Qur'an Hadis Pendekatan Saintifik Kurukulum 2013 Madrasah Aliyah Kelas X. Jakarta : Kementerian Agama RI

Manna khalil al-Qattan. (2011). Studi Ilmu-Ilmu Qur'an. Bogor: Pustaka Litera Antar Nusa

Muhammad, N. (2014). Pengembangan Model Pembelajaran Al-Qur'an Hadis Madrasah Alliyah (MA) di Samarinda. Jurnal Al-Qalam, 20(1);9-24 
Rully, I \& Poppy, Y. (2014). Metedologi Penelitian kuantitatif, Kualitatif dan Campuran untuk Manajemen, Pembangunan dan Pendidikan. Bandung : PT. Refika Aditama.

Sugiyono.(2009). Statistika Untuk Penelitian. Jakarta : Alfabeta

Tim Baitul Kilmah Jogjakarta. (2017). Ensiklopedia Pengetahuan Al-Qur'an dan Hadits. Jakarta: Kamil Pustaka. 